\title{
Analysis of Flyover Construction Effect to Increase Traffic Services and Reduce Exhaust Emissions at an Intersection
}

\author{
Lily Triani \\ Departement of Civil Engineering \\ Sriwijaya University \\ Palembang, Indonesia
}

\author{
Joni Arliansyah* \\ Departement of Civil Engineering \\ Sriwijaya University \\ Palembang, Indonesia
}

\author{
Melawaty Agustien \\ Departement of Civil Engineering \\ Sriwijaya University \\ Palembang, Indonesia
}

\begin{abstract}
Patal - Pusri Intersection is one of the intersections in Palembang with heavy traffic flow and frequent traffic jams. The existence of Underpass construction, apparently could not be a complete solution to unravel traffic congestion. The purpose of this research is to analyze five alternative scenario plans to disentangled the vehicle density, congestion, and reduce pollution from exhaust emissions caused by vehicle density. This research was conducted using VISSIM Microsimulation Program assistance to simulate existing alternative scenarios and to analyze the effect of these alternative scenarios on reducing vehicle exhaust emissions using the EnViVer Program assistance. The results showed that the fifth alternative scenario as the flyover construction, geometric changes at the intersection's leg crossing, and traffic lights rearrangement became the most effective alternative and was able to parse vehicle density and traffic congestion, and was able to reduce exhaust emissions by $32.36 \%$. This was shown by the reduction in queue length by $44 \%$ and the delay times by $57.05 \%$, and the reduction in exhaust emissions in the form of carbon dioxide (CO2) by 35.5\%, nitrogen oxides (NOx) by 43\%, and particulate matter (PM10) ) by $18.6 \%$ at the intersection significantly.
\end{abstract}

Keywords:- flyover, VISSIM Microsimulation Program, EnViVer Program, delay times, queue length, exhaust emissions.

\section{INTRODUCTION}

Palembang is one of the largest cities in Indonesia with rapid population growth. As population growth continues to increase, transportation activities in Palembang also more increasing. One of the densities that often happens is in Patal - Pusri Intersection Palembang. The intersection with four connecting arterial roads which are, Jl. MP. Mangkunegara, Jl. R. Abdul Rozak, Jl. AKBP Cek Agus, and Jl. R. Soekamto is among the busy intersections because of their geometric location which is between 4 densely populated sub-districts. The four densely populated subdistricts are Kalidoni, Ilir Timur II, Ilir Timur III, and Kemuning which also contribute to the density of traffic flow that every day always meets the intersection.

Underpass construction has been carried out at this intersection by connecting Jl. R. Abdul Rozak and Jl. R. Soekamto as an effort to reduce the density of traffic flow [1]. However, it could be seen from the number of LHR at the Patal - Pusri Intersection recorded in the Survey Traffic Data Recap based on Bina Marga Vehicle Classes by the PJN Region 2 Work Unit of South Sumatra Province, a decline from 24,598 vehicles/hour in 2014 to 13,559 vehicles/hour in 2015 showed that these efforts were considered insufficient to be a perfect solution. The density of the vehicle that caused congestion occurred on Jl. AKBP Cek Agus to Jl. MP. Mangkunegara and vice versa.

The vehicle density at the intersection can affect pollution at the intersection [2], [3]. Pollution is produced by motorized vehicles that experience long queues and time delays which cause traffic congestion. Pollutants or vehicle exhaust emissions produced by motorized vehicles include carbon monoxide $(\mathrm{CO})$, carbon dioxide $(\mathrm{CO} 2)$, nitrogen oxides (NOx) in the form of nitric oxide (NO) and nitrogen dioxide (NO2), hydrocarbons ( $\mathrm{HC}$ ) sulfur oxide ( $\mathrm{SOx}$ ) in the form of sulfur dioxide (SO2) and sulfur trioxide (SO3) and particulate matter (PM10).

Based on existing conditions, several alternative scenarios were planned, in the form of traffic lights rearrangement [4],[5], intersection geometric changes [6], and flyover construction [7],[8],[9],[10],[11]. Alternative scenarios were simulated using the Vissim Microsimulation Program. The simulation results would produce a queue length and time delay which were used as parameters of the successful alternative scenario. The alternative scenario simulation results were then analyzed further to see improvements in the performance of intersections to vehicle exhaust emissions produced using the EnViVer Program [12], [13], [14], [15]. 
The purpose of this research is to analyze the influence of the developed alternative scenarios in breaking down traffic congestion and reducing pollution from exhaust emissions at the Patal - Pusri Intersection Palembang.

\section{RESEARCH METHOD}

\section{A. Research Site}

This research was conducted at the Patal - Pusri Intersection Palembang which included Jl. MP. Mangkunegara, Jl. R. Abdul Rozak, Jl. AKBP Cek Agus, and Jl. R. Soekamto as segments of the intersection's leg crossing. The location plan of the research is shown in Figure 1.

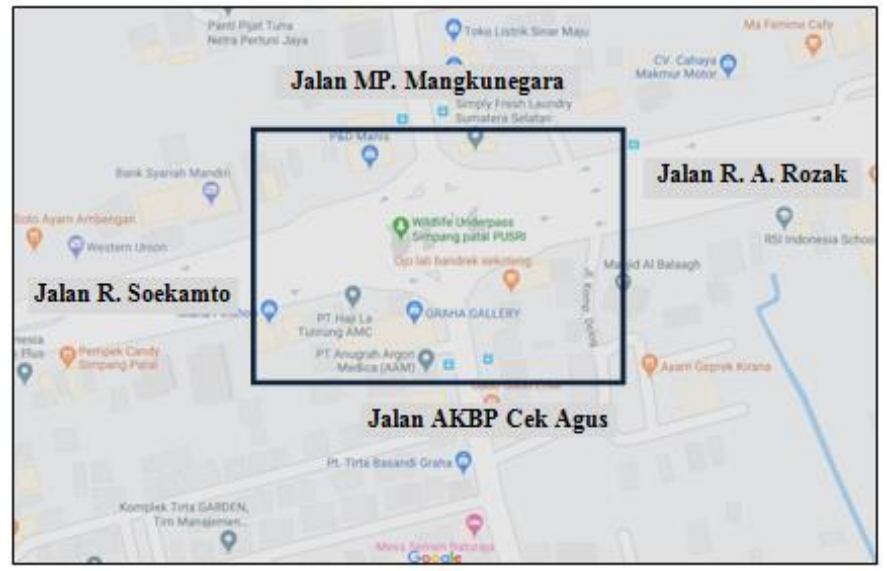

Fig 1:- Research Site, The Patal - Pusri Intersection Palembang

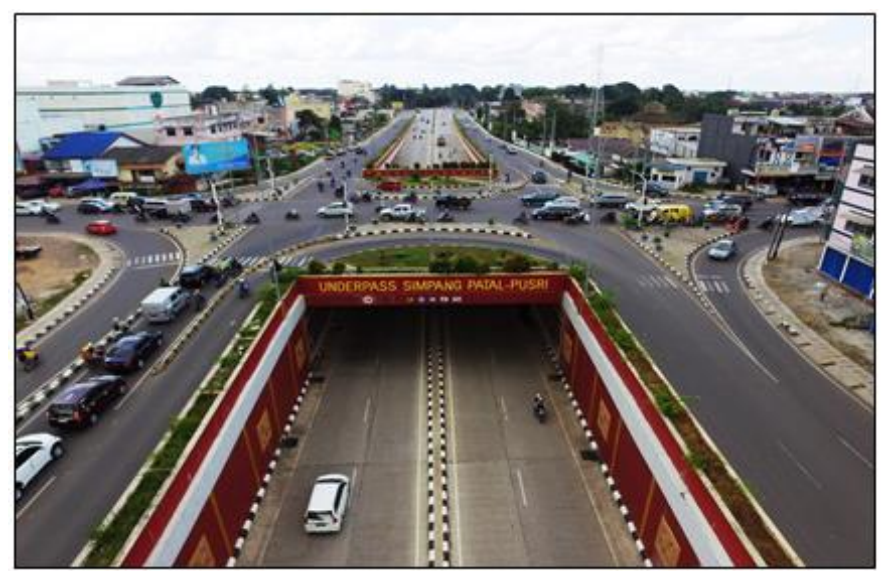

Fig 2:- The Underpass Patal - Pusri Intersection Palembang

At the research site, the underpass was built which connects Jl. R. Soekamto and Jl. R. Abdul Rozak and vice versa. The Underpass Patal - Pusri Intersection Palembang can be seen in Figure 2.

\section{B. Data Collection}

Data collected through surveys at the Palembang Patal - Pusri Intersection include road geometric data, vehicle volume data, traffic light cycle data, and vehicle speed data. This traffic survey was conducted by observing the time where the intersections that are reviewed reach the maximum density or the most traffic jam peak point.

\section{Traffic Performance Analysis}

Traffic performance analysis was conducted by using the Vissim Microsimulation Program. The results of the simulation program include the length of the queue, the time delay, and vehicle exhaust emissions. To find simulation results that were close to the results of existing conditions, several experiments would be carried out to find the calibration and validation values that fulfill out.

Based on the simulation results of the existing conditions, then developed several alternative scenarios that could be used to reduce the queue length, delay time, and exhaust emissions resulting from the previously existing conditions. The developed alternative scenarios at the Patal Pusri Intersection Palembang, include :

The first alternative was traffic light rearrangement.

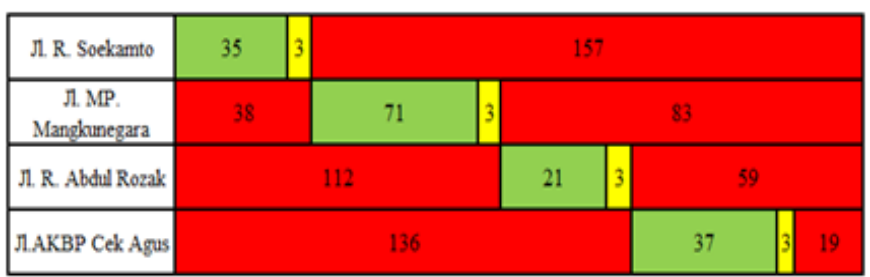

(a)

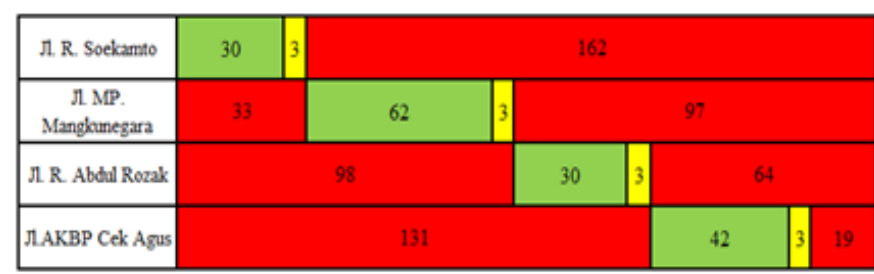

(b)

Fig 3:- First Alternative Scenario, (a). Existing Traffic Light Cycles and (b). Alternative Traffic Light Cycles

In the existing condition cycle, Jl. R. Abdul Rozak only has a cycle of green light for 21 seconds, while Jl. MP. Mangkunegara has a 71-second green light cycle. The traffic cycle time of each road section causes a long queue length so that the traffic flow becomes too dense. This cycle time imbalance then causes traffic delays which affect the overall traffic at the Palembang Patal - Pusri Intersection.

By using the trial and error system which is carried out on each cycle of the road section at this intersection, the traffic light cycle settings are obtained which affect the improvement of the intersection performance.

The second alternative was the geometric changes at the intersection's leg crossing.

Figure 4(a). shows the existing condition where Jl. R. Soekamto has only 3 tracks, which are one turn left, one turn right, and one U-Turn. 
Therefore several changes were made such as Figure 4(b), which are :

- the addition of a certain 4-meter wide track for road users who will turn left on Jl. R. Soekamto to Jl. MP. Mangkunegara

- the addition of an extra track on Jl. R. Soekamto segment with a 4 meters wide for road users who will turn right to Jl. AKBP Cek Agus, so that the taken track by road users to turn right becomes 2 tracks

The changes made to Jl. R. Soekamto will also be made to Jl. R. Abdul Rozak.

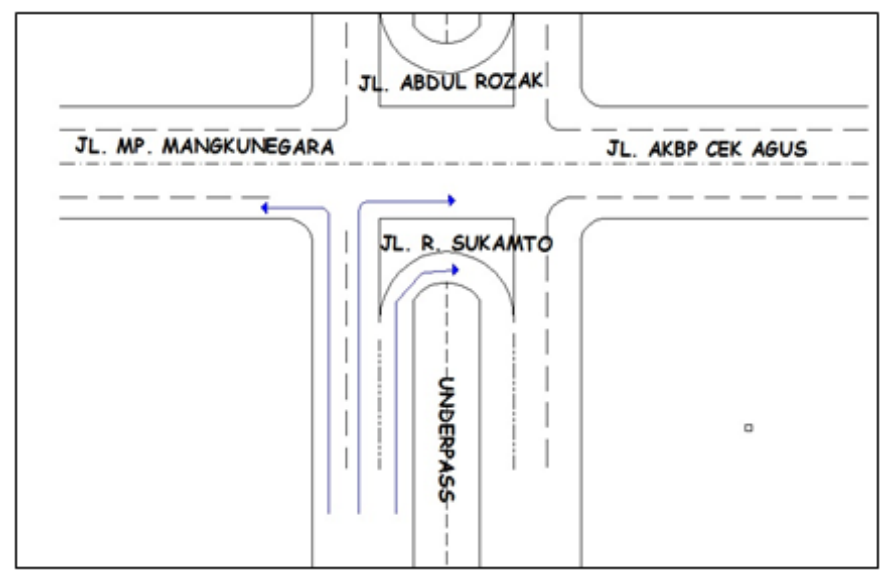

(a). Existing condition

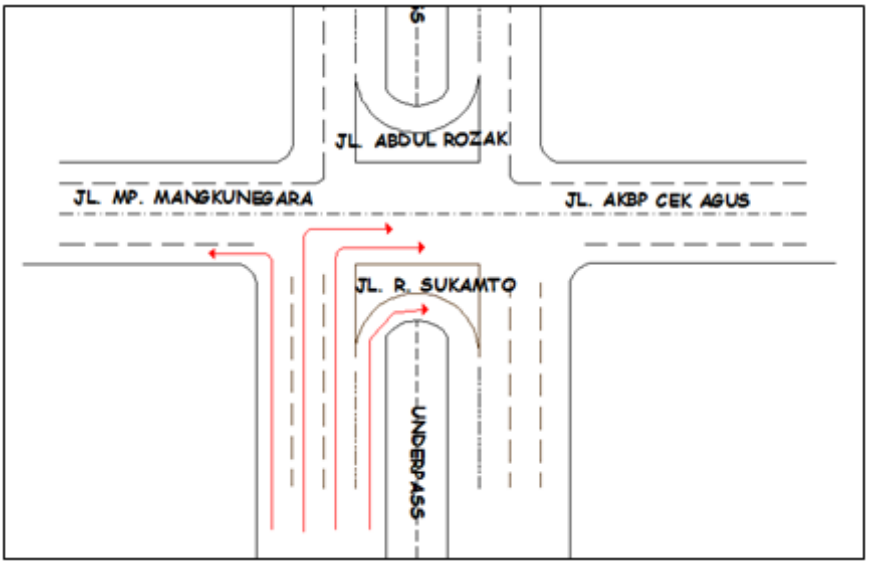

(b). Geometric Changes Planning

Fig 4:- The Second Alternative Scenarios, Intersection's Leg Crossing Geometric Changes

The third alternative was the combination of the first alternative and the second alternative, which were the rearrangement of traffic lights and geometric changes at the intersection's leg crossing.

The fourth alternative was the flyover construction and geometric changes at the intersection's leg crossing.

Figure 5 showing the construction of a flyover. Based on the intersection's leg crossing condition, there will be made some changes which are :
- the construction of a flyover on Jl. MP. Mangkunegara section to Jl. AKBP Cek Agus

- the addition of an extra track of each road section which the Flyover will be build to avoid the growth of the vehicle at Flyover's point 0

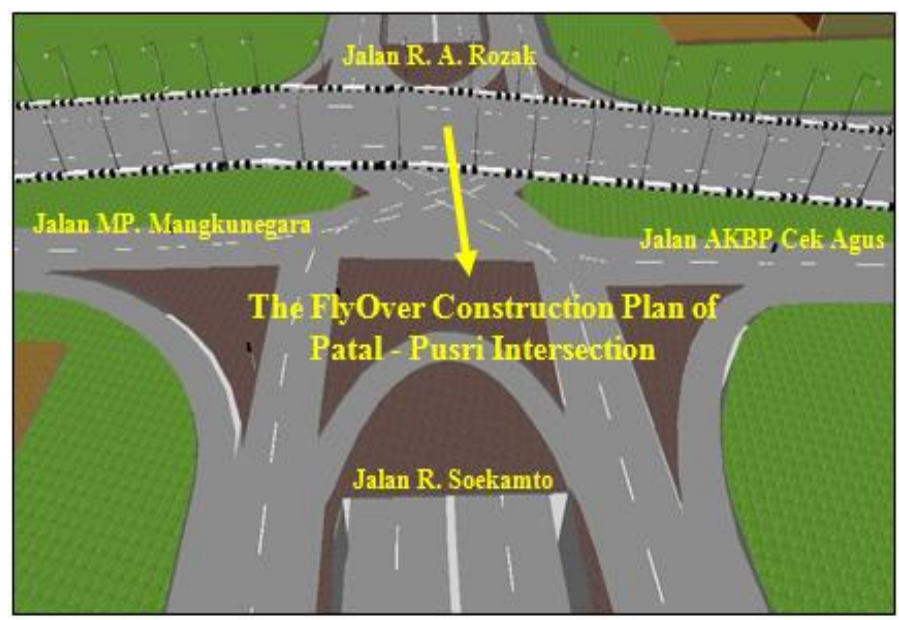

Fig 5:- The forth scenarios alternative, Flyover Construction and Geometric Changes on the Intersection's Leg Crossing

The fifth alternative, was the combination of traffic lights rearrangement, geometric changes at the intersection leg crossing, and the flyover construction.

The simulation results from the five alternative scenarios then analyzed to get the best alternative to solve the traffic problems, then output the simulation results in the form of *.fzp file used to analyze the exhaust emissions using the EnViVer Program. Exhaust emissions which can be analyzed in the form of carbon dioxide $\left(\mathrm{CO}_{2}\right)$, nitrogen oxides $\left(\mathrm{NO}_{\mathrm{x}}\right)$, and Particulate Matter $\left(\mathrm{PM}_{10}\right)$.

\section{RESULT AND DISCUSSION}

\section{A. The Calibration of Existing Condition}

The traffic volume from the survey results was simulated using a program that was then calibrated and validated, the traffic volume in the form of the vehicle number from the survey results and the simulation results are shown in Table 1.

Total Number of Vehicle

\begin{tabular}{lcc} 
Name of Street & $\begin{array}{c}\text { Survey 's Result } \\
\text { (Veh/Hour) }\end{array}$ & $\begin{array}{c}\text { VISSIM Simulation Result } \\
\text { (Veh/Hour) }\end{array}$ \\
\hline Jalan MP. Mangkunegara & 4183 & 3012 \\
\hline Jalan R. Abdul Rozak & 2917 & 2159 \\
\hline Jalan AKBP Cek Agus & 3695 & 2697 \\
\hline Jalan R. Soekamto & 3159 & 2243 \\
\hline
\end{tabular}

Table 1:- The Comparison of Total Number of Vehicle Survey Results and Simulation Results 
From the vehicle volume results in Table 1, the total number of vehicles that produce the average calibration value of each road at the intersection was $72.5 \%$. The calibration results obtained were considered good enough to represent the existing condition of the field at the Patal Pusri intersection.

\section{B. The Analysis of Existing Conditions and Alternative Scenarios for the Traffic Performance of Palembang's Patal-Pusri Intersection}

Table 2 showed a performance summary of the Patal Pusri Intersection in the form of queue length and delay time obtained from the simulation results of the existing conditions, where there was a long queue and a considerable delay occurred on Jl. MP. Mangkunegara and Jl. AKBP Cek Agus. Long queue value in the longest existing condition was on Jl. MP. Mangkunegara which was 187.374 meters long to 74.94 meters. While the time delay value in the longest existing condition was on Jl. AKBP Cek Agus which was 379.73 seconds to 102.52 seconds. This showed that the intersection's traffic service performance at the Patal - Pusri Intersection was not good enough.

The analysis results of the existing conditions and the five alternative scenarios of the simulation results are shown in Figure 6 and Figure 7. It can be seen the length of the queue and the delay time of the existing conditions and the developed alternative scenarios, showing alternative 5 as the rearrangement of traffic lights, geometric changes at the intersection's leg crossing, and flyover construction was a very effective and optimal alternative solution in improving traffic performance at the Patal - Pusri Intersection.

\begin{tabular}{|c|c|c|c|c|c|c|c|}
\hline $\begin{array}{c}\text { Street } \\
\text { Approach } \\
\text { Name }\end{array}$ & Attribute & Existing & $\begin{array}{c}\text { The } 1^{\text {st }} \\
\text { Altemative }\end{array}$ & $\begin{array}{c}\text { The } 2^{\text {nd }} \\
\text { Altemative }\end{array}$ & $\begin{array}{c}\text { The } 3^{\text {rd }} \\
\text { Altemative }\end{array}$ & $\begin{array}{c}\text { The } 4^{\text {th }} \\
\text { Altemative }\end{array}$ & $\begin{array}{c}\text { The } 5^{\text {th }} \\
\text { Altemative }\end{array}$ \\
\hline $\begin{array}{c}\text { J1. MP. } \\
\text { Mangkunegara }\end{array}$ & The Vehicle Volume & 3012 & 3054 & 3061 & 3184 & 3317 & 3482 \\
\cline { 2 - 8 } & The Queue Length (m) & 187,374 & 172,38408 & 163,01538 & 157,39416 & 84,3183 & 74,9496 \\
\cline { 2 - 8 } & The Delay Times (sec) & 324,876 & 298,88592 & 277,11923 & 237,15948 & 113,7066 & 94,21404 \\
\hline \multirow{2}{*}{$\begin{array}{c}\text { J1. R. Abdul } \\
\text { Rozak }\end{array}$} & The Vehicle Volume & 2159 & 2101 & 2132 & 2166 & 2223 & 2311 \\
\cline { 2 - 8 } & The Queue Length (m) & 57,329 & 53,029325 & 47,58307 & 47,00978 & 42,99675 & 41,27688 \\
\cline { 2 - 8 } & The Delay Times (sec) & 126,441 & 116,95793 & 102,41721 & 98,62398 & 78,39342 & 72,07137 \\
\hline \multirow{3}{*}{$\begin{array}{c}\text { J1. AKBP Cek } \\
\text { Agus }\end{array}$} & The Vehicle Volume & 2697 & 2734 & 2741 & 2784 & 2891 & 3006 \\
\cline { 2 - 8 } & The Queue Length (m) & 168,484 & 154,66831 & 144,89624 & 141,52656 & 72,44812 & 70,76328 \\
\cline { 2 - 8 } & The Delay Times (sec) & 379,736 & 348,59765 & 318,97824 & 269,61256 & 117,71816 & 102,52872 \\
\hline \multirow{2}{*}{$\begin{array}{c}\text { J1. R. } \\
\text { Soekamto }\end{array}$} & The Vehicle Volume & 2243 & 2274 & 2319 & 2339 & 2438 & 2532 \\
\cline { 2 - 8 } & The Queue Length (m) & 89,628 & 84,25032 & 74,39124 & 72,59868 & 65,42844 & 62,7396 \\
\cline { 2 - 8 } & The Delay Times (sec) & 174,658 & 164,17852 & 143,21956 & 139,7264 & 103,04822 & 102,6989 \\
\hline
\end{tabular}

Table 2:- The Recapitulation of Simulation Results on Existing Condition and Alternative Scenarios

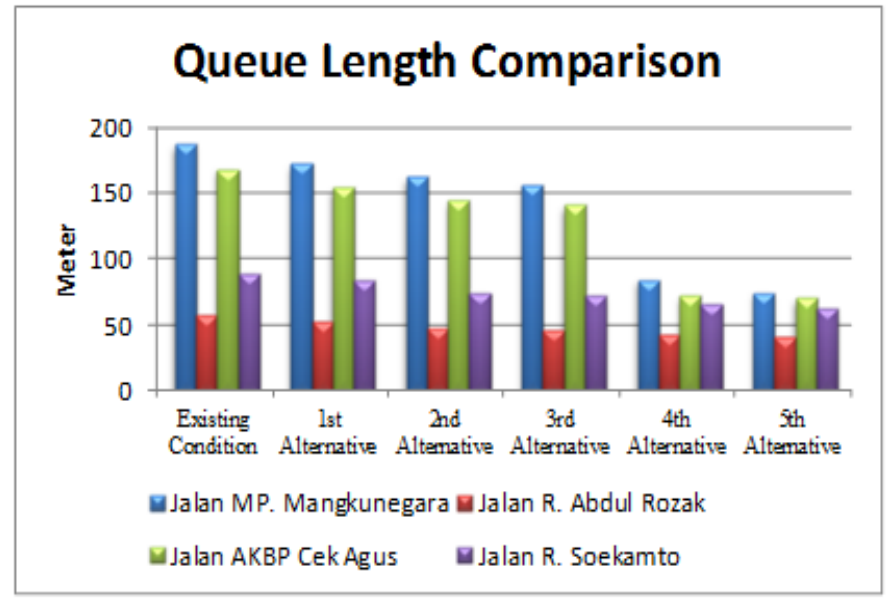

Fig 6:- The Comparison of Existing Conditions Queue Length and Alternative Scenarios

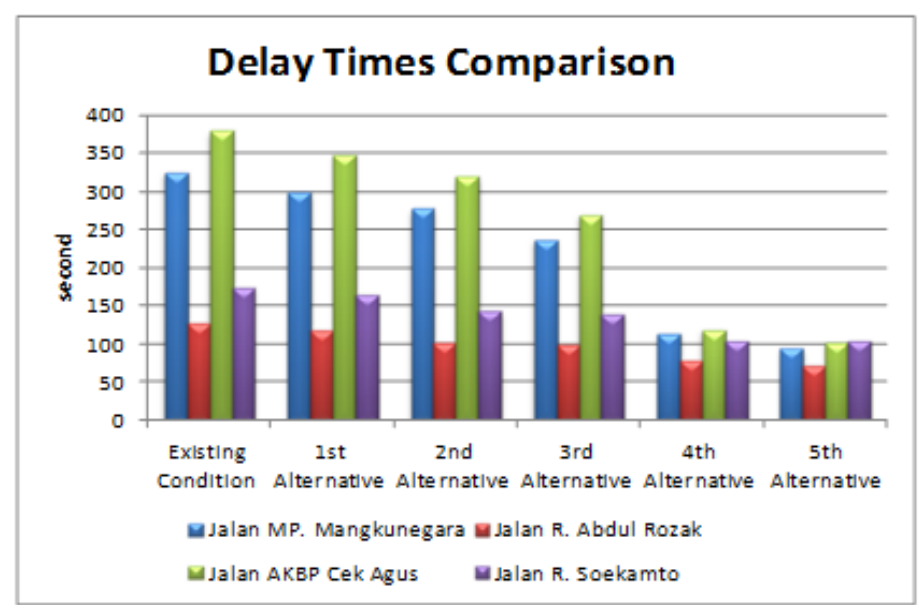

Fig 7:- The Comparison of Existing Condition Delay Times and Alternative Scenarios 
C. The Vehicle Exhaust Emission Analysis at the Patal Pusri Palembang's Intersection

The analysis results of exhaust emissions were carried out to determine the total value of emissions produced by both the existing conditions and the conducted five alternative scenarios. The total value of vehicle exhaust emissions in the existing conditions is shown in Figure 8 and the gradation concentration level for each vehicle exhaust emissions in Figure 9.

\begin{tabular}{|ccc|}
\hline \multicolumn{1}{|c|}{ Emission } & & \\
\hline $\mathrm{CO}_{2}$ & $\mathrm{NO}$ & $\mathrm{PM}$ \\
\hline $138.035 \mathrm{~kg}$ & $431.106 \mathrm{~g}$ & $23.916 \mathrm{~g}$ \\
\hline $829.595 \mathrm{~kg} / \mathrm{h}$ & $2590.954 \mathrm{~g} / \mathrm{h}$ & $143.737 \mathrm{~g} / \mathrm{h}$ \\
\hline $270.670 \mathrm{~g} / \mathrm{km}$ & $845.345 \mathrm{mg} / \mathrm{km}$ & $46.897 \mathrm{mg} / \mathrm{km}$ \\
\hline
\end{tabular}

\begin{tabular}{|c|c|c|}
\hline \multicolumn{3}{|l|}{$\begin{array}{l}\text { Eksisting } \\
\text { Total emission: }\end{array}$} \\
\hline $\mathrm{CO} 2$ & NOx & PM10 \\
\hline $1.38 \mathrm{e}+05 \mathrm{~g}$ & $431.1 \mathrm{~g}$ & $23.92 \mathrm{~g}$ \\
\hline $8.296 \mathrm{e}+05 \mathrm{~g} / \mathrm{h}$ & $2591 \mathrm{~g} / \mathrm{h}$ & $143.7 \mathrm{~g} / \mathrm{h}$ \\
\hline $270.7 \mathrm{~g} / \mathrm{km}$ & $0.8453 \mathrm{~g} / \mathrm{km}$ & $0.0469 \mathrm{~g} / \mathrm{km}$ \\
\hline
\end{tabular}

Fig 8:- Total Existing Vehicle Exhaust Gas Emissions Generated by the EnViVer Program

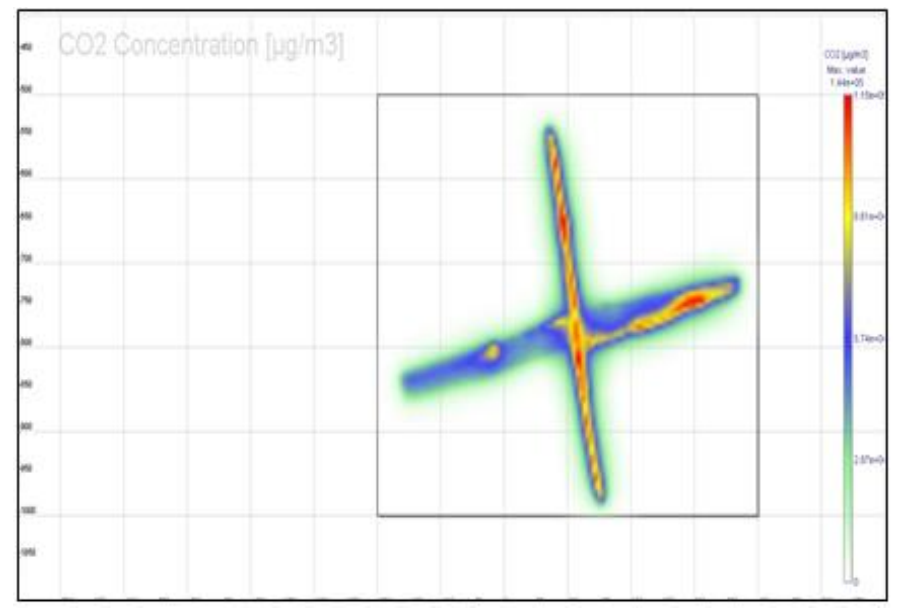

(a)

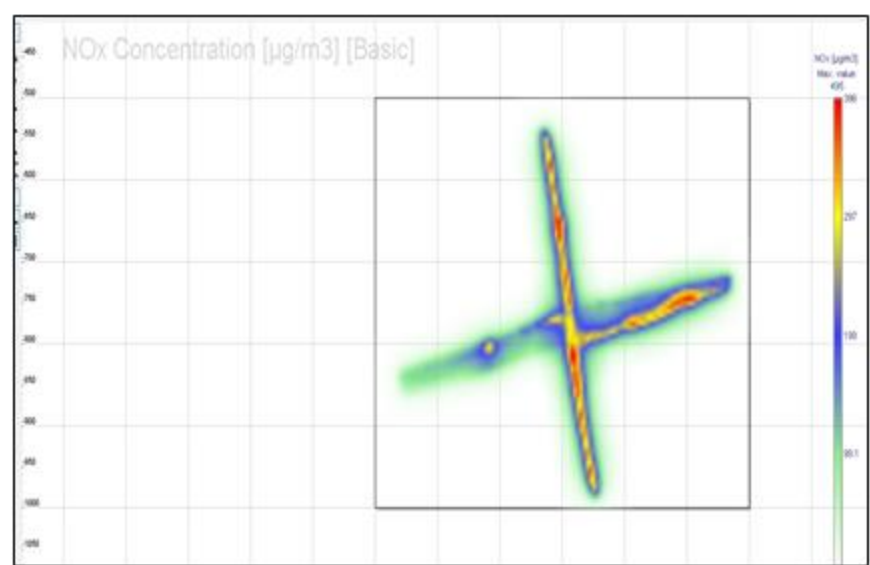

(b)

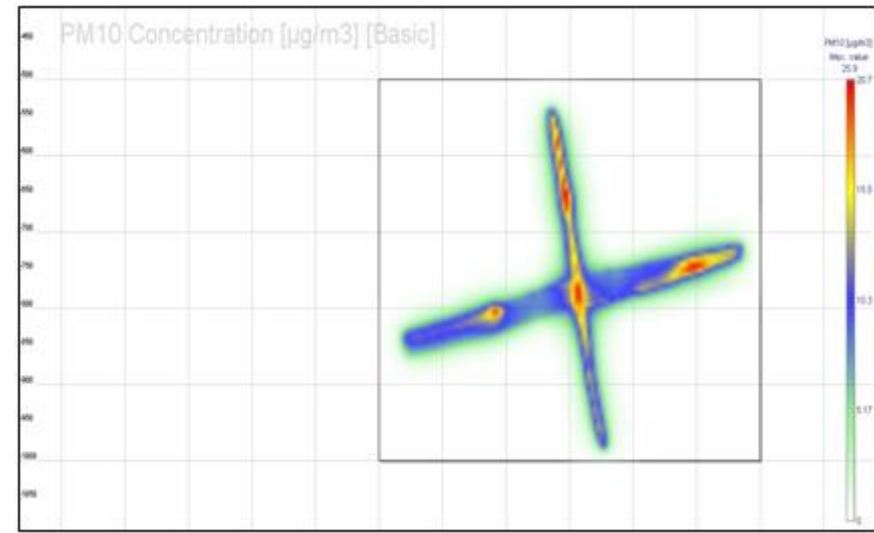

(c)

Fig 9:- The Gradation Concentration Level (a) $\mathrm{CO}_{2}$, (b) $\mathrm{NO}_{x}$, (c) $\mathrm{PM}_{10}$ Existing Vehicle Exhaust Conditions Generated by the EnViVer Program

Based on figure 8 , in the existing conditions of $\mathrm{CO}_{2}$ emissions of $270.67 \mathrm{~g} / \mathrm{km}$, NOx exhaust emissions of 845.3 $\mathrm{mg} / \mathrm{km}$, and $\mathrm{PM}_{10}$ exhaust emissions of $46.889 \mathrm{mg} / \mathrm{km}$. Whereas in Figure 9, the concentration of vehicle exhaust emissions $\left(\mathrm{CO}_{2}\right)$ with the highest traffic plot display from the EnViver program was shown by the gradation of red with a value of $115,000 \mu \mathrm{g} / \mathrm{m}^{3}$, the gradation of yellow with a value of $86,100 \mu \mathrm{g} / \mathrm{m}^{3}$, the gradation of blue with a value of $57400 \mu \mathrm{g} / \mathrm{m} 3$, and green gradation with a value of 28,700 $\mu \mathrm{g} / \mathrm{m}^{3}$. The highest concentration of NOx pollutant emissions was indicated by the gradation of red with a value of $396 \mu \mathrm{g} / \mathrm{m}^{3}$, the gradation of yellow with a value of 297 $\mu \mathrm{g} / \mathrm{m}^{3}$, the gradation of blue with a value of $198 \mu \mathrm{g} / \mathrm{m}^{3}$, and the gradation of green with a value of $99.1 \mu \mathrm{g} / \mathrm{m}^{3}$. The highest concentration of $\mathrm{PM}_{10}$ pollutant emissions was indicated by a gradation of red with a value of $20.7 \mu \mathrm{g} / \mathrm{m}^{3}$, a gradation of yellow with a value of $15.5 \mu \mathrm{g} / \mathrm{m}^{3}$, a gradation of blue with a value of $10.3 \mu \mathrm{g} / \mathrm{m}^{3}$, and a gradation of green with a value of $5,17 \mu \mathrm{g} / \mathrm{m}^{3}$. Gradation showed the maximum and minimum limit values of each concentration on vehicle exhaust emissions produced. 
The results of motor vehicle exhaust emissions produced by the EnViVer Program for existing conditions and the five alternative scenarios were conducted at the
Palembang Patal - Pusri Intersection is recapitulated in Table 3.

\begin{tabular}{|c|c|c|c|}
\hline & \multicolumn{3}{|c|}{ Total Exhaust Emissions } \\
\hline & $\mathrm{CO}_{2}$ & $\mathrm{NO}$ & $\mathrm{PM}$ \\
\hline & $\mathrm{g} / \mathrm{km}$ & $\mathrm{mg} / \mathrm{km}$ & $\mathrm{mg}$ \\
\hline Existing & 270,67 & 845,345 & 46,897 \\
\hline The $1^{\text {st }}$ Alternative & 238,012 & 731,087 & 38,368 \\
\hline The $2^{\text {nd }}$ Alternative & 241,738 & 779,885 & 44,406 \\
\hline The $3^{\text {rd }}$ Alternative & 225,061 & 691,121 & 40,031 \\
\hline The $4^{\text {th }}$ Alternative & 177,936 & 461,008 & 35,058 \\
\hline The $5^{\text {th }}$ Alternative & 174,557 & 481,689 & 38,193 \\
\hline
\end{tabular}

Table 3:- The Comparison of Exhaust Emission Results for Existing Conditions and All Developed Alternatives

Table 3 showed that the three types of pollutants from vehicle exhaust emissions had decreased in each developed alternatives. The Comparison results of exhaust gas profits for existing conditions and all developed alternatives can be seen in Figure 10. A significant decrease occurred in the fourth alternative and the fifth alternative. However, alternative 5 had a good impact on reducing exhaust emissions at the Patal-Pusri Palembang's Intersection.

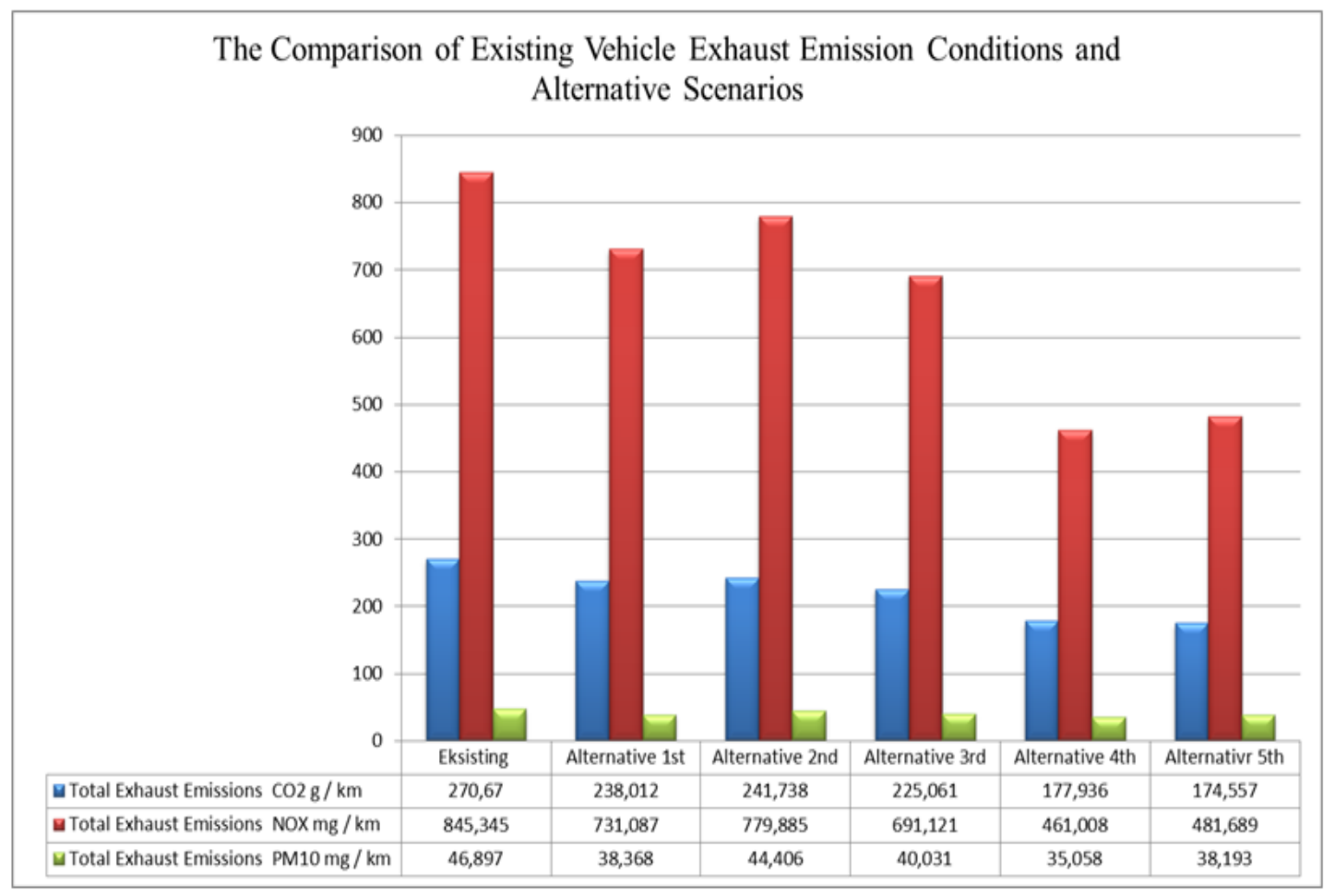

Fig 10:- The Comparison of Existing Vehicle Exhaust Emission Conditions and Alternative Scenarios at the Patal - Pusri Intersection of Palembang

\section{CONCLUSIONS}

Based on the data analysis results which has been done, it can be concluded that :

$>$ The traffic performance in the existing condition showed that during peak hour conditions at the Patal-Pusri Intersection could no longer serve traffic well. This was shown from the significant value of the queue length and the time delay from the analys.

$>$ From the five developed alternative scenarios, it was found that the most optimal alternative scenario in improving the performance of the Patal - Pusri
Intersection's traffic service was alternative scenario 5 which were the traffic lights rearrangement, geometric changes at the intersection's leg crossing, and flyover construction. The fifth alternative could reduce the queue length and delay time significantly and that was the best alternative to improve the performance of traffic services at the Patal-Pusri Palembang's Intersection. In alternative scenario 5, the longest queue length was $\mathrm{Jl}$. MP. Mangkunegara which indicates 74.95 meters long, then followed by Jl. AKBP Cek Agus for 70.76 meters, then 62.73 meters for Jl. R. Soekamto and Jl. R. Abdul Rozak for 41.27 meters. While the longest delay was on 
the Jl. AKBP Cek Agus, it became 102.52 seconds, followed by Jl. MP. Mangkunegara for 94.21 seconds, then Jl. R. Soekamto for 102.69 seconds and Jl. R. Abdul Rozak for 72.07 seconds.

With a significant decrease in queue length and time delays in alternative scenario 5, vehicle exhaust emissions had also decreased. This could be seen in the total $\mathrm{CO}_{2}$ emissions of existing and alternative 5 conditions of $270.67 \mathrm{~g} / \mathrm{km}$ to $174.557 \mathrm{~g} / \mathrm{km}$, NOx exhaust emissions of $845.345 \mathrm{mg} / \mathrm{km}$ to 481.689 $\mathrm{mg} / \mathrm{km}$, and $\mathrm{PM}_{10}$ exhaust emissions of $46,897 \mathrm{mg} / \mathrm{km}$ to $38,193 \mathrm{mg} / \mathrm{km}$. The fifth alternative was also the best alternative to reduce exhaust emissions.

\section{REFERENCES}

[1]. B. Y. Hendrawan and R. Nurmeyliandari, "Analisa Tarikan Pergerakan Lalu Lintas Sebelum Dan Sesudah Pembangunan Underpass Simpang Patal Palembang," Jurnal Deformasi Universitas PGRI, Volume 2, Nomor 1, Januari - Juni 2017.

[2]. J. Arliansyah and R. T. Bawono, "Analysis of the Emission Reduction through Performance Improvement of Intersection and Network nearby Using Micro Simulation Program," Open Transportation Journal, Vol. 12, No. 1, pp. 332-343, 2018.

[3]. J. Arliansyah and R. T. Bawono, "Study on Performance of Intersection Around The Underpass Using Micro Simulation Program," IOP Conf. Ser.: Earth Environ. Sci., Vol. 124, No. 1, 2018.

[4]. R. Setiawan., "Simulasi Manajemen Lalu Lintas Untuk Mengurangi Kemacetan Di Jalan Jemursari Dan Raya Kendangsari," Jurnal Teknik Sipil, Vol-3 No.1 Universitas Kristen Petra, Surabaya, 2018.

[5]. Tarigan, T. S. A., Surbakti, M. S., "Simulasi Koordinasi Rambu Lalu Lntas Terhadap Volume Kendaraan Saat Waktu Puncak Lalu Lintas Di Persimpangan Menggunakan Software Vissim," Engineering Journal of Civil Engineering, Vol.2 No.2 Universitas Sumatera Utara, Medan, 2016.

[6]. F. Kurniawan and Sudarno, "Analisis Geometrik Pada Tikungan Ruas Jalan Raya Magelang-Kopeng Dan Jalan Raya Soekarno-Hatta (Pertigaan Canguk)," Reviews in Civil Engineering, v.02, n.1, p.52-57, Universitas Tidar Magelang, Maret 2018.

[7]. A. A. R. T. Gerung, J. A. Timboeleng, J. E. Waani, "Kajian Lalu Lintas Pada Rencana Pembangunan Fly Over Maumbi Persimpangan Maumbi, ” Jurnal Ilmiah Media Engineering Vol. 5 No. 1 Universitas Sam Ratulangi Manado, 2015.

[8]. B. Maitra, M. Azmi, N. Kumar, and J. R. Sarkar, "Modeling Traffic Impact of Flyover at an Urban Intersection Under Mixed Traffic Environment,' European Transport Vol. 27, pp. 57-68, 2004.

[9]. A. Maji, A. K. Maurya, S. Nama, and P. K. Suhu, "Performance-based intersection layout under a flyover for heterogeneous traffic," J. Mod. Transport, Vol. 23 No. 2, pp.119-129,2015.
[10]. R. Akter, H. Khatun, "Impact Of Jillur Rahman Flyover On Road Transportation System Of Mirpur, Dhaka," Oriental Geographer Vol. 58, No. 2, 2017.

[11]. N. Salatoom and P. Taneerananon, "A Study of a Flyover-Bridge - Improved Intersection, ” Engineering Journal Volume 19 Issue 1, pp.1-12,2015.

[12]. A. R. Pratama, J. Arliansyah, and M. Agustien, "Analysis of Air Pollution due to Vehicle Exhaust Emissions on The Road Networks of Beringin Janggut Area,” J. Phys. Conf. Ser., Vol. 1198, No. 8, 2019.

[13]. C. Linton, S. Grant-Muller, and W. F. Gale, "Approaches and Techniques for Modelling CO2 Emissions from Road Transport," Transport Rev., Vol. 35, No. 4, pp. 533-553, 2015.

[14]. M. L. Adha, J. Arliansyah, E. Buchari, “Analysis of the Influence of Traffic Flow on Air Pollution at Simpang Angkatan 66 of Palembang City,” J. Phys. Conf. Ser., Vol. 1198, No. 8, 2019.

[15]. E. Raudhati, J. Arliansyah, E. Buchari, "An Analysis of Air Quality through the Basis of Traffic Performance of Signaled Intersections, " J. Phys. Conf. Ser., Vol. 1198, No. 8, 2019. 